\title{
Hunting and Monitoring: Community- Based Research in Xerente Indigenous Land, Brazilian Cerrado
}

\author{
Milton de Paula' \\ Postgraduate Program in Ecology \\ University of Pará, Belém, Brazil \\ Valcir Xerente \\ Environmental Engineer \\ Salto Village, Tocantínia, Brazil \\ Juarez Pezzuti \\ Center for Advanced Amazon Studies \\ University of Pará, Belém, Brazil
}

\section{Abstract}

Community-based research that involves participatory monitoring has been increasingly used in studies on hunting activity in traditional societies of the Neotropics, particularly in the rainforest environment. We present the results from a year-long study of participatory monitoring of hunting in 10 villages in Xerente indigenous land in the Brazilian Cerrado, an initiative to build a sustainable-use program for local hunting. Fifty-two hunters recorded data on 390 hunts involving 451 kills and 5,878 kg of estimated biomass from 34 game species. Medium- and large-sized mammals were the most hunted species, while hunting activities were predominant in forest environments. Indigenous hunting techniques associated with collective hunts using fire are no longer used, and the use of traditional weapons such as the bow and arrow is now uncommon; firearms were the main weapon used. The data revealed current patterns of wildlife use as well as hunting activities. The implications of these results for future research on the management and conservation of wildlife hunting in Xerente indigenous land are presented. We present our findings to facilitate improved preparation of new monitoring programs in traditional societies that live in the Cerrado.

Keywords: conservation, game hunting, participatory monitoring, traditional people

1 Corresponding author: sdabupre@gmail.com 


\section{Introduction}

Hunting is an important practice for forest dwellers in the Neotropics, providing important food sources for subsistence and helping maintain cultural practices and socioeconomic systems (Robinson \& Redford, 1991; Shepard, 2014). The sustainable use of wildlife is essential to the long-term use of this resource (Constantino et al., 2008). Many of these groups have adopted management schemes based on continued resource evaluation through community-based natural resource monitoring programs as a strategy for sustainable wildlife management (Berkes, 2004; Brown, 2003). This strategy has, in many cases, contributed to effective results in sustainable wildlife management, as well as promoting local empowerment of the community (Constantino et al., 2012). Furthermore, it has been important in countries with low research investment where participatory systems have proven to be faster and more efficient in influencing decision-making processes (Brown, 2003; Constantino et al., 2012; Moller et al., 2004).

One of the fundamental principles of community-based natural resource monitoring programs is the self-monitoring of harvest by resource users themselves (Danielsen et al., 2005), where they are trained for this function. In this paper we use the term "participatory monitoring." Participatory monitoring programs have been increasingly used in studies on hunting activities of indigenous and nonindigenous traditional societies in the Neotropics (Constantino et al., 2008; Hill et al., 1997; Luzar et al., 2011; Noss et al., 2005; Ohl-Schacherer et al., 2007; Pezzuti et al., 2004; Read et al., 2010; Vieira et al., 2015). Accordingly, part or most of the data on hunting activity has been collected by the hunters themselves, or by other community members. These programs target the collection of indicators which enable assessment of resource use in space and time, with the participation of experts in the area and the local population (Ferraz et al., 2008; Luzar et al., 2011). In addition, this provides great benefits to research because, when using participatory monitoring, spatial coverage and range is increased by several orders of magnitude over what is typically feasible for an individual researcher during a single season of fieldwork (Luzar et al., 2011; Shepard et al., 2012).

In turn, the use of participatory monitoring has made it possible to evaluate the impacts of hunting on wildlife populations, spatial and temporal patterns, and cultural use of the resource. It has also enabled forecasting of hunting impact scenarios, and interactions between anthropogenic and ecological aspects of game hunting in computational modeling (Iwamura et al., 2014; Shepard et al., 2012).

Many studies on community-based monitoring of hunting activities have taken place in the Neotropics, particularly in the Amazon Basin (Bodmer \& Puertas, 1999; Constantino et al., 2008; Lopes et al., 2012; Luzar et al., 2011; Ohl-Schacherer et al., 2007; Pezzuti et al., 2004; Vieira et al., 2015). In contrast, few studies regarding 
natural resource use and monitoring have been carried out within the Cerrado, the second-largest biome in Brazil. In addition, this typical Brazilian habitat is currently subjected to the highest rate of destruction in the country, having lost half of its original cover to pasture, crop fields and other anthropogenic land uses (Klink \& Machado, 2005). Only $1.5 \%$ of its total area is protected (Trolle et al., 2006). The area of Xerente indigenous land (XIL) preserves a significant area of this biome and has high potential for maintaining the biodiversity of one of the world's biodiversity hotspots (Myers et al., 2000).

In this paper we present the results of a year-long participatory monitoring of hunting study in 10 villages in XIL, an initiative to build a sustainable-use program for local hunting and a way of obtaining information on the exploitation of local game. We also show the importance of these results in revealing the current patterns of use of the local wildlife, and the implications participatory monitoring of hunting has for future management and conservation plans in XIL and for other traditional groups that exploit the Cerrado biome.

\section{Akwẽ-Xerente people}

The Xerente belong to the Jê linguistic family and are speakers of the Akwẽ language. They make up the subgroup Akwẽ along with the Xavante and Xacriabá people, which are known as the central Jê groups. Their contact with non-indigenous society dates back to the sixteenth century and began to intensify in the eighteenth century (Farias, 1994). This period was characterized by fierce conflicts between the Xerente and non-indigenous people, which ended in 1851 with a settlement in the town of Tereza Cristina or Piabanhas (the present city of Tocantínia) (Giraldin \& Silva, 2002). The first Xerente territory was demarcated in 1972, followed by demarcation of the Funil territory in 1991.

The Akwẽ-Xerente people exploit their surrounding environment for subsistence through hunting, gathering, fishing, family agriculture, and raising of livestock (such as chickens, pigs, and cattle). Some individuals have jobs as teachers, health workers, employees of the National Indian Foundation (FUNAI), drivers, merchants, and city officials. Those who manage to enter higher education receive scholarships. Other sources of income include the sale of handicrafts and surplus fishing, collecting, family farming, and breeding animals. 


\section{Methods}

\section{Study area}

XIL ( $\left.9^{\circ} 34^{\prime} 37.4^{\prime \prime} \mathrm{S}, 48^{\circ} 06^{\prime} 38.3^{\prime \prime} \mathrm{W}\right)$ is located in the municipality of Tocantínia, Tocantins state, and covers 183,542 hectares (Figure 1). The population in 2010 was 3,017 people (IBGE, 2010) distributed across 62 villages.

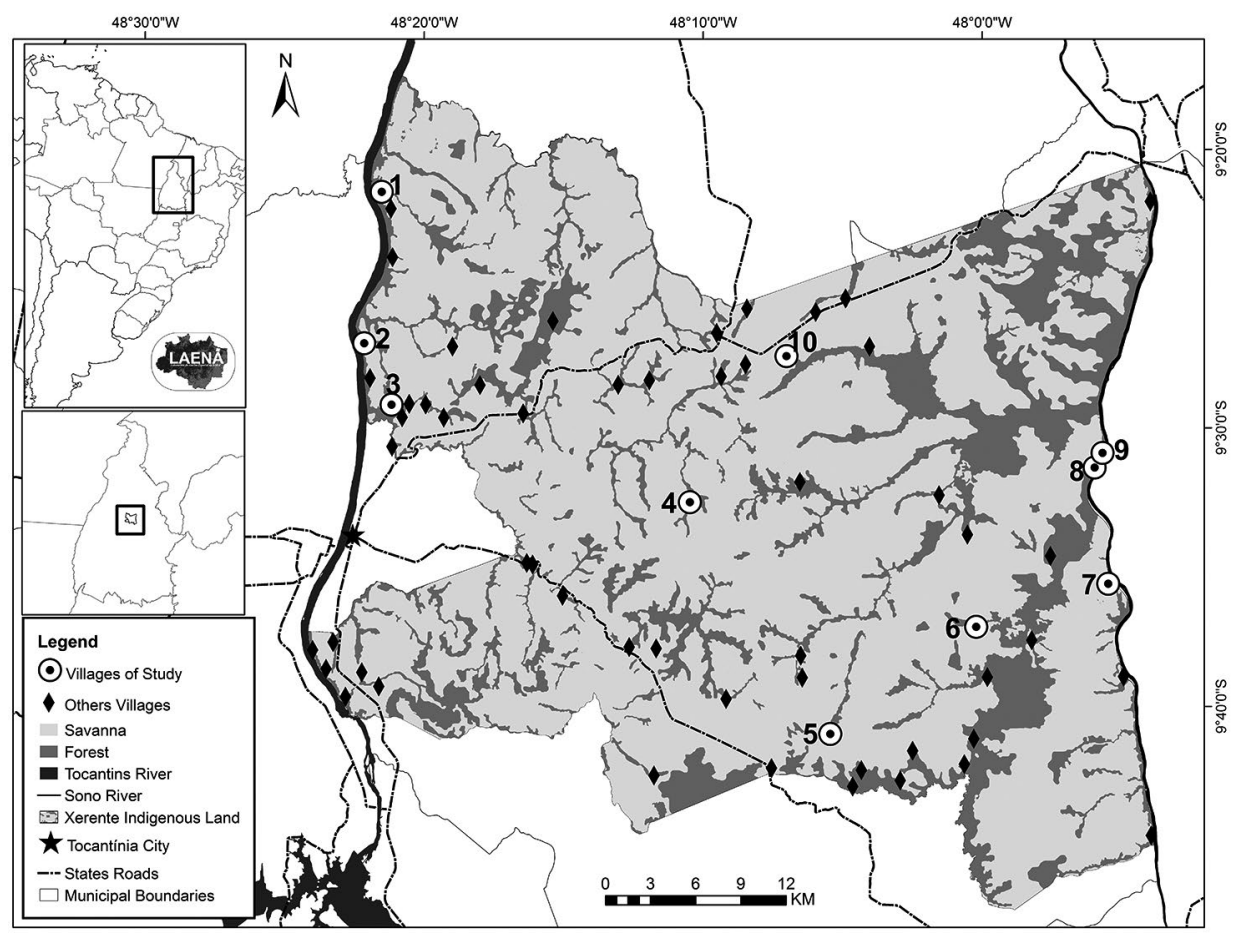

Figure 1. Location of Xerente indigenous land and villages participating in the study: (1) Bela Vista, (2) Porteira, (3) Salto, (4) Cahoeirinha, (5) Brejo Cumprido, (6) Ktẽpô, (7) Rio Sono, (8) Sangradouro, (9) Brejo Novo, (10) Bupré

Source: National Indian Foundation, Brazilian Institute of Geography, and Statistics and United States Geological Survey.

XIL lies within the Cerrado biome. The Cerrado is 1.86 million $\mathrm{km}^{2}$ in area, possessing the richest flora among the world's savannas $(>7,000$ species) and high levels of endemism (Klink \& Machado, 2005; da Silva \& Bates, 2002). The biome is characterized by various vegetation types: cerrado (dense, typical, and sparse), vereda (a seasonally flooded area dominated by palm trees), rocky fields (savanna environment) and cerradão (typical forest patches of cerrado), and gallery and riparian forests (Ribeiro \& Walter, 2008). There are 194 mammalian and 830 bird species 
known, and the biome is the third-most diverse area in Brazil after the Amazon rainforest and Atlantic Forest. In general, mammal fauna essentially comprise smallsized animals: $85 \%$ of species have a body mass no greater than $5 \mathrm{~kg}$ and only five species weigh more than $50 \mathrm{~kg}$ (Marinho-filho et al., 2002). The climate is humid with a moderate seasonal water deficit, an average daily temperature of $28{ }^{\circ} \mathrm{C}$ and $1,700-1,800 \mathrm{~mm}$ average annual rainfall.

\section{Implementation of participatory monitoring of hunting}

For implementation of participatory monitoring of hunting we chose 10 villages (out of 62) representative of the age range of the villages and straight-line distances $(\mathrm{km})$ from the nearby town of Tocantínia (Figure 1, Table 1). The center of each village was recorded with a GPS (global positioning system) device and distances were measured using ArcGIS 9.3.2 software. Some Xerente helped in village selection. Work in selected villages was authorized by signed consent presented by the village chief.

In each village, hunters older than 18 years were invited to participate on a voluntary basis, and those who accepted signed an informed consent form agreeing to participate. Hunters with whom we had previous contact helped in the selection of additional collaborators.

\section{Data collection and analysis}

Hunters were instructed to fill monitoring data sheets with the following information for each hunting event: (1) date, (2) village, (3) hunter, (4) type of environment, (5) hunting technique, (6) hunting gear, (7) hunting with or without success, (8) number of kills per species, (9) weight $(\mathrm{kg})$ of each animal killed, and (10) sex of each animal killed. Practice runs were conducted individually or in groups. Each hunter received $20-50 \mathrm{~kg}$ spring scales to measure the weight of kills.

The first author remained in the villages for six consecutive months to support the hunters with their monitoring activity in order to ensure the quality of their data collection. We also conducted semi-structured and open interviews with hunters in order to obtain additional data on wildlife use (e.g., hunting techniques, food preferences, and taboos).

The distinct vegetation types in which hunting occurred were grouped into the following environments: cerrado, forest (riparian and gallery forest and cerradão), and vereda. Aquatic environments were classified as clearings and marginal vegetation (riparian vegetation, sandbars, and rocky outcrops) on the banks of the Tocantins and Sono rivers (Figure 1). Species names in the native language were identified with the help of the Xerente people and a Xerente-Portuguese/Portuguese-Xerente dictionary (Krieger \& Krieger, 1994). 
The total number of kills and biomass obtained $(\mathrm{kg})$ for the 10 monitored villages was estimated using the average kills and biomass per hunter who returned complete data sheets $(n=48)$. These values were then multiplied by the total number of hunters in these villages. The sex ratio of eight species was calculated as the number of males for every 100 females.

\section{Results}

Fifty-two out of 55 hunters agreed to collaborate in the study. Three individuals were not indigenous hunters. However, as they lived in the villages and were married to Xerente women they were included in the study. Data collection took place from March 2014 to February 2015. Two hunters did not return their monitoring sheets and a further two did not return all of their sheets due to their absence from the villages during collection periods (during the first six months and at the end of the study). Some Xerente hunters have cell phones or smartphones with internet access, allowing data sharing through phone calls or social media. The 50 participating hunters represented $91 \%$ of all hunters in the 10 monitored villages (Table 1).

Table 1. Villages included in participatory monitoring of hunting in Xerente indigenous land, in order of total estimated obtained biomass, March 2014 - February 2015

\begin{tabular}{|l|c|c|c|c|c|c|c|c|c|}
\hline Village & A & $\begin{array}{c}\text { DC } \\
(\mathbf{k m})\end{array}$ & NPH & TNH & NHE & NKA & $\begin{array}{c}\text { OBW } \\
(\mathbf{k g})\end{array}$ & $\begin{array}{c}\text { EOB } \\
(\mathbf{k g})\end{array}$ & $\begin{array}{c}\text { TEO } \\
(\mathbf{k g})\end{array}$ \\
\hline Salto & 22 & 8 & $14^{\mathrm{a}}$ & 15 & 119 & 135 & 1,865 & 345 & 2,211 \\
\hline Porteira & 74 & 13 & $12^{\mathrm{b}}$ & 14 & 90 & 108 & 853 & 258 & 1,111 \\
\hline Bela Vista & 84 & 22 & 7 & 7 & 68 & 71 & 902 & 63 & 965 \\
\hline Rio Sono & 114 & 48 & $6^{\mathrm{c}}$ & 6 & 31 & 39 & 352 & 83 & 435 \\
\hline $\begin{array}{l}\text { Brejo } \\
\text { Cumprido }\end{array}$ & 34 & 31 & 3 & 3 & 21 & 24 & 305 & 106 & 412 \\
\hline Cahoeirinha & 9 & 18 & 1 & 1 & 18 & 23 & 202 & 88 & 289 \\
\hline Brejo Novo & 14 & 48 & $2^{\mathrm{d}}$ & 3 & 25 & 31 & 170 & 58 & 228 \\
\hline Ktẽpô & 9 & 37 & 1 & 1 & 7 & 8 & 140 & 0 & 140 \\
\hline Sangradouro & 14 & 48 & 4 & 4 & 10 & 11 & 81 & 0 & 81 \\
\hline Bupré & 15 & 28 & $1^{\mathrm{c}}$ & 2 & 1 & 1 & 6 & 0 & 6 \\
\hline Total & - & - & 51 & 56 & 390 & 451 & 4,876 & 1,001 & 5,878 \\
\hline
\end{tabular}

Note. $A=$ age of village; $D C=$ distance from Tocantínia city; $N P H=$ number of hunters participating in monitoring; $\mathrm{TNH}$ = total number of hunters; NHE = number of hunting events (successful hunts only); $\mathrm{NKA}=$ number of killed animals; OBW = obtained biomass weight; $\mathrm{EOB}$ = estimated obtained biomass (see Table 2); TEO = total estimated obtained biomass.

a One hunter was not indigenous. ${ }^{\mathrm{b}}$ Two hunters were not indigenous. ${ }^{c}$ One hunter did not deliver all his monitoring sheets. ${ }^{d}$ One hunter did not deliver his monitoring sheets. 
During the monitoring period, 451 animals were killed in 390 successful hunts, totaling 4,876 kg of biomass ( $n=371$ weighed animals). However, 80 animals were not weighed, so for these cases the species' mean body mass was used, resulting in a total estimated biomass of 5,878 kg. At least 47 hunts were unsuccessful, but this is an underestimate as most hunters did not correctly record these events; therefore, unsuccessful hunts were not considered in the results.

Using data from 48 hunters who completed all data sheets, we estimated the total number of kills and obtained biomass for the 10 study villages. The average number of kills and biomass per hunter was 9.2 and $120 \mathrm{~kg}$ respectively. Multiplying these values by the total number of hunters in the villages gives an estimate of 506 kills and $6,600 \mathrm{~kg}$ of obtained biomass for all villages.

Salto village had the highest number of participating hunters, which also resulted in the largest number of hunting events, kills, and obtained biomass (Table 1). Non-indigenous hunters were responsible for $11.3 \%(n=44)$ of all hunting events, $14.4 \%(n=65)$ of all kills, and $15.7 \%(924 \mathrm{~kg})$ of obtained biomass.

Thirty-four species were killed including 23 species of medium to large mammals, nine species of bird, and two species of reptile (Table 2). Six species killed are considered vulnerable: Lycalopex vetulus (hoary fox) (MMA, 2014), Myrmecophaga tridactyla (giant anteater) (IUCN, 2014; MMA, 2014), Ozotoceros bezoarticus (pampas deer), Puma yagouaroundi (jaguarundi) (MMA, 2014), Tapirus terrestris (tapir), and Tayassu pecari (white-lipped peccary) (IUCN, 2014; MMA, 2014). Leopardus sp. (wild cat), hoary fox, and Tupinambis sp. (tegu lizard) were not consumed for their meat by hunters. A young individual of Tamandua tetradactyla (collared anteater) and one Mazama gouazoubira (brown brocket deer) were captured to be raised as pets (xerimbabos). Fourteen species were killed by both non-indigenous and Xerente hunters, while jaguarundi, Procyon cancrivorus (crab-eating raccoon), and Sapajus apella (tufted capuchin) were killed only by the non-indigenous hunters.

Table 2. Species recorded in participatory monitoring of hunting in Xerente indigenous land, in order of total estimated obtained biomass, March 2014 - February 2015

\begin{tabular}{|l|c|c|c|c|c|}
\hline Species name (popular name) & Xerente name & NKA $^{\mathrm{b}}$ & $\begin{array}{c}\text { OBW } \\
(\mathbf{k g})\end{array}$ & $\begin{array}{c}\text { EOB }^{\mathrm{d}} \\
\mathbf{( k g})\end{array}$ & $\begin{array}{c}\text { TEO } \\
\mathbf{( k g})\end{array}$ \\
\hline Tapirus terrestris (tapir) & Kdâ & $9(2)$ & 1,278 & 160 & 1,438 \\
\hline Pecari tajacu (white-collared peccary) & Kuhârê & $51(9)$ & 750 & 47 & 797 \\
\hline Hydrochoerus hydrochaeris (capybara) & Kumdâ & 14 & 558 & 40 & 598 \\
\hline Ozotoceros bezoarticus (pampas deer) & Aze & 29 & 294 & 211 & 505 \\
\hline Mazama gouazoubira (brown brocket deer) & Ponkẽrê & $34(4)$ & 456 & 44 & 500 \\
\hline Tayassu pecari (white-lipped peccary) & Kuhâ & $15(5)$ & 227 & 224 & 451 \\
\hline Mazama americana (red brocket deer) & Ponẽ & $13(1)$ & 343 & 30 & 373 \\
\hline
\end{tabular}




\begin{tabular}{|c|c|c|c|c|c|}
\hline Species name (popular name) & Xerente name & $\mathrm{NKA}^{\mathrm{b}}$ & $\begin{array}{c}\text { OBW } \\
(\mathrm{kg})\end{array}$ & $\begin{array}{c}\mathrm{EOB}^{\mathrm{d}} \\
(\mathrm{kg})\end{array}$ & $\begin{array}{l}\text { TEO } \\
(\mathrm{kg}) \\
\end{array}$ \\
\hline Cuniculus paca (paca) $)^{a}$ & Krawa & $55(4)$ & 299 & 43 & 342 \\
\hline $\begin{array}{l}\text { Dasypus novemcinctus (nine-banded } \\
\text { armadillo)a }\end{array}$ & Wrãku & $42(15)$ & 160 & 17 & 177 \\
\hline Myrmecophaga tridactyla (giant anteater) & Padi & 6 & 106 & 57 & 163 \\
\hline Dasyprocta sp. ${ }^{\mathrm{c}}\left(\right.$ agouti) $^{\mathrm{a}}$ & Zâwri & $54(3)$ & 129 & 22 & 151 \\
\hline Rhea americana (greater rhea) & Mã & 3 & 47 & 33 & 80 \\
\hline Nasua nasua (coati) & Wakõ & 18 & 47 & 19 & 66 \\
\hline Penelope superciliaris (rusty-margined guan) ${ }^{\mathrm{a}}$ & Akkapre & $41(7)$ & 36 & 10 & 46 \\
\hline Tamandua tetradactyla (collared anteater) ${ }^{\mathrm{a}}$ & Patrê & $9(2)$ & 28 & 8 & 36 \\
\hline Euphractus sexcinctus (yellow armadillo) ${ }^{a}$ & Wrãpakrda & $7(2)$ & 26 & 0 & 26 \\
\hline Paleosuchus palpebrosus (caiman) & Kuihâ & 2 & 21 & 0 & 21 \\
\hline $\begin{array}{l}\text { Dasypus septemcinctus (long-nosed } \\
\text { armadillo) }\end{array}$ & Sipsĩmrê & $13(6)$ & 8 & 12 & 20 \\
\hline $\begin{array}{l}\text { Coendou prehensilis (prehensile-tailed } \\
\text { porcupine) }\end{array}$ & Samrõ & 4 & 9 & 4 & 13 \\
\hline Crax fasciolata (bare-faced curassow) & Akka & 5 & 12 & 0 & 12 \\
\hline Cerdorcyonthous (crab-eating fox) & Wapsã wara & 2 & 9 & 0 & 9 \\
\hline Sapajus apella (tufted capuchin) & Kro & (3) & 0 & 9 & 9 \\
\hline Cabassou sunicinctus (naked-tailed armadillo) & Wrãknõ & 5 & 8 & 0 & 8 \\
\hline Leopardu ssp. (wildcat) & Pattêrê kumto & 1 & 0 & 6 & 6 \\
\hline Lycalopex vetulus (hoary fox) & $\begin{array}{l}\text { Wapsã wara } \\
\text { wasterê }\end{array}$ & 1 & 6 & 0 & 6 \\
\hline Puma yagouaroundi (jaguarundi) & Pattêrêwakú & (1) & 6 & 0 & 6 \\
\hline Procyon cancrivorus (crab-eating racoon) & Wapsã pra po & (1) & 0 & 5 & 5 \\
\hline Arara arauna (blue-and-yellow macaw) & Soîte & 3 & 4 & 0 & 4 \\
\hline Cariama cristata (red-legged seriema) & Wakrdi & 2 & 3 & 0 & 3 \\
\hline Aramides sp. (wood-rail) & Kratdu & 2 & 3 & 0 & 3 \\
\hline Crypturelllus undulatus (undulated tinamou) ${ }^{a}$ & Nõzâkmõ & $3(1)$ & 2 & 0 & 2 \\
\hline Tupinambis sp. (tegu lizard) & Asadâ & 1 & 1 & 0 & 1 \\
\hline Crypturellus parvirostris (small-billed tinamou) & Amtrorê & 1 & 0.5 & 0 & 0.5 \\
\hline Amazonas sp. (parrot) & Wa & 1 & 0.5 & 0 & 0.5 \\
\hline Total & & 451 & 4,877 & 1,001 & 5,878 \\
\hline
\end{tabular}

Note. NKA = number of killed animals; OBW = obtained biomass weight; $E O B$ = estimated obtained biomass; TEO = total estimated obtained biomass.

${ }^{\text {a }}$ Species also killed by non-indigenous hunters. ${ }^{b}$ Numbers in parentheses refer to total killed by nonindigenous hunters. ${ }^{\circ}$ Two species, Dasyprocta prymnolopha and $D$. iacki, occur within the study area (MJP, unpublished data); however, their identification at the species level in the survey was not possible. ${ }^{d}$ Mean biomass calculated by specimens weighed in the survey for the following species: white-collared peccary $(n=44)$, capybara $(n=14)$, agouti $(n=46)$, rusty-margined guan $(n=32)$, bare-faced curassow $(n=5)$, paca $(n=48)$, coati $(n=14)$, nine-banded armadillo $(n=38)$, pampas deer $(n=17)$, brown brocket deer $(n=30)$, red brocket deer $(n=12)$. For all other species see Emmons \& Feer (1990), Nowak (1999), Peres \& Palacios (2007), and Sick (1986). 
Medium- and large-sized mammals were the most hunted, comprising $87 \%(n=392)$ of total kills and $97 \%(5,718 \mathrm{~kg})$ of total estimated biomass. Birds comprised $12 \%$ $(n=56)$ and $2 \%(137 \mathrm{~kg})$ of total kills and total estimated biomass, followed by reptiles with $1 \%(n=3)$ and $1 \%(22 \mathrm{~kg})$, respectively. In terms of biomass, the most representative species was the tapir $(n=1,440 \mathrm{~kg})$. In numbers, Cuniculus paca (paca) ( $n=55)$, Dasyprocta sp. (agouti) $(n=54)$, Pecari tajacu (white-collared peccary) $(n=51)$, and Dasypus novemcinctus (nine-banded armadillo) $(n=42)$ were the most representative. The species most killed were primarily those with a smaller mean body biomass (Figure 2).

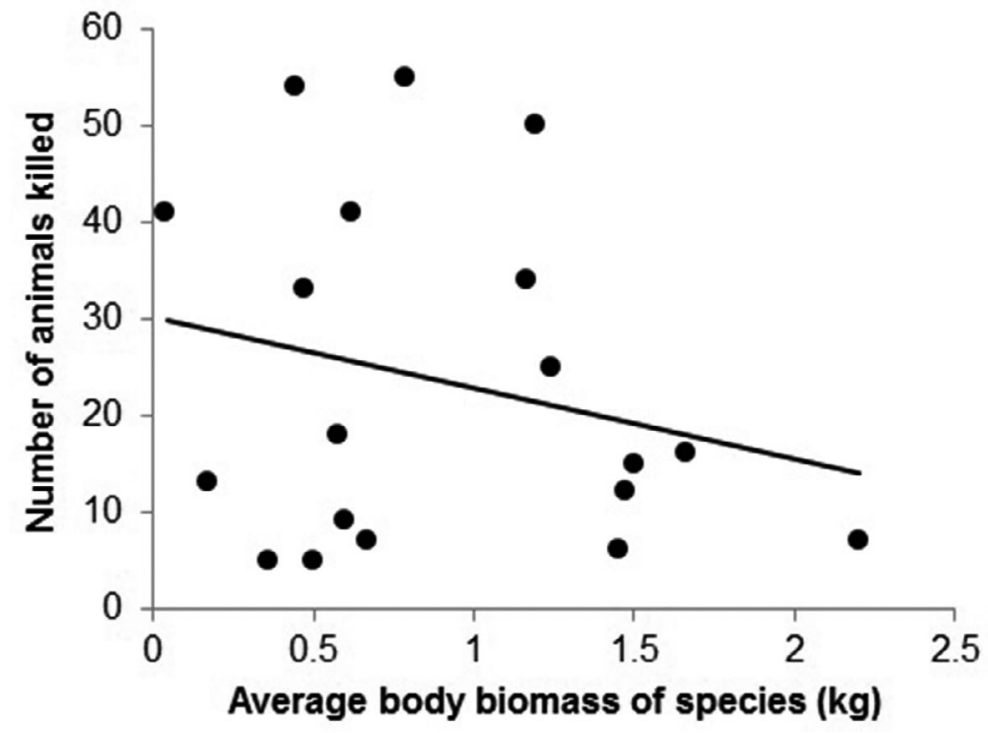

Figure 2. Relationship between number of killed individuals and mean (values transformed in log) body biomass of hunted species recorded in participatory monitoring of hunting in Xerente indigenous land, March 2014 - February 2015

Note. Only species accounting for more than $1 \%$ of the number of animals killed and obtained biomass ( $n=19)$ were included. See Table 2 for the references used for mean body biomass.

Table 3 shows data on hunting events for each environment. Most $(n=259,66 \%)$ hunting events took place in forest environments, which provided the largest number of kills $(n=311)$ and biomass $(3,890 \mathrm{~kg})$. Cerrado, the prevailing environment in XIL, was the second-most exploited with $20 \%(n=79)$ of all hunting events, 86 kills, and $1,022 \mathrm{~kg}$ of biomass produced. 
Table 3. Exploited environments recorded during participatory monitoring of hunting in Xerente indigenous land, in order of total estimated obtained biomass, March 2014 - February 2015

\begin{tabular}{|l|c|c|c|}
\hline Environment & Hunting events $(\boldsymbol{n})$ & Animals killed ( $)$ & $\begin{array}{c}\text { Total estimated } \\
\text { obtained biomass (kg) }\end{array}$ \\
\hline Forest & 259 & 311 & 3,890 \\
\hline Cerrado & 79 & 86 & 1,022 \\
\hline Marginal vegetation & 12 & 13 & 444 \\
\hline Vereda & 24 & 25 & 292 \\
\hline Farm & 14 & 14 & 209 \\
\hline Water & 2 & 2 & 21 \\
\hline Total & 390 & 451 & 5,878 \\
\hline
\end{tabular}

Nine hunting strategies were recorded during the participatory monitoring of hunting study: waiting, walking, walking with dog, canoe, canoe with dog, hole, sweep, trabuco, and opportunistic kills. Each technique with its corresponding number of hunting events, kills, and biomass per environment is given in Table 4. See Box 1 for a brief explanation of each hunting technique.

The walking technique was the most used $(n=164,42 \%)$, was responsible for the most kills $(n=194)$, and ranked second in returned biomass $(2,092 \mathrm{~kg})$. Its application was prevalent in forest environments $(n=83)$. Waiting was the second-most used technique ( $n=139,35.6 \%)$, returning the second-largest number of kills $(n=166)$ and most of the biomass $(2,393 \mathrm{~kg})$. This technique was used almost exclusively in forests $(n=131)$.

Table 4. Hunting techniques recorded during participatory monitoring of hunting in Xerente indigenous land, in order of estimated obtained biomass, March 2014 - February 2015

\begin{tabular}{|l|c|c|c|c|c|c|c|c|}
\hline \multirow{2}{*}{ Technique } & \multicolumn{4}{|c|}{} & \multicolumn{5}{c|}{ Events per environment $(\boldsymbol{n})$} \\
\cline { 2 - 10 } & HE $(\boldsymbol{n})$ & KA $(\boldsymbol{n})$ & TEO (kg) & Cerrado & Forest & Farm & $\begin{array}{c}\text { Marginal } \\
\text { vegetation }\end{array}$ & Vereda \\
\hline Waiting & 139 & 166 & 2,393 & 5 & 131 & 3 & - & - \\
\hline Walking & 164 & 194 & 2,092 & 57 & 83 & 1 & - & 23 \\
\hline Canoe with dog & 11 & 11 & 430 & - & - & - & 11 & - \\
\hline Sweep & 19 & 19 & 365 & - & 19 & - & - & - \\
\hline Walking with dog & 15 & 17 & 201 & 5 & 9 & - & - & 1 \\
\hline Trabuco & 15 & 15 & 138 & - & 12 & 3 & - & - \\
\hline Opportunistic & 18 & 18 & 124 & 12 & 4 & 2 & - & - \\
\hline Canoe & 8 & 10 & 94 & - & - & - & 8 & - \\
\hline Hole & 1 & 1 & 40 & - & - & 1 & - & - \\
\hline Total & 390 & 451 & 5,878 & - & - & - & - & - \\
\hline
\end{tabular}

Note. $\mathrm{HE}=$ hunting events; $\mathrm{KA}=$ killed animals; TEO = total estimated obtained biomass. 


\section{Box 1. Brief explanation of each hunting technique used by hunters in Xerente indigenous land}

Waiting: The hunter uses a laced network on a tree or builds a perch and stays in the treetop waiting for the target species. Areas next to the feeding (fallen fruits are preferred) or drinking trails of the target species are chosen to employ this technique. Night kills are made with the help of a flashlight.

Walking: The hunter walks and tracks the traces (footprints, burrows, smell, feeding areas) left by the animal until finding the target species. This technique is predominantly performed in the morning, and is done with the help of a flashlight at night. Mainly motorcycles, but also bicycles and motor vehicles, are used to access locations further away.

Walking with dog: Dogs are used to follow signs of prey and pursue them. Once the prey is located, the dog's barking indicates they have cornered their prey (acuarem) and the hunters follow the barking and attempt to kill the animal (Alves et al., 2009).

Canoe: This technique is predominantly performed at night, when the hunter slowly steers a canoe along the major rivers to get close to animals that are near the riverbanks.

Canoe with dog: Dogs move along the riverbanks while the hunter follows them in a canoe. The aim is for the dogs to detect the prey and chase it into the water. Once the prey is in the water, the hunter gets close with the canoe and kills the animal.

Hole: Holes are strategically dug along animal trails to trap prey. When an animal falls into a hole, it is easily found and killed.

Sweep: The hunter chooses a trail to use. He removes leaves and sticks from the soil-a cleaning or sweep of the trail. The purpose of this is to avoid producing any sounds that could alert the target species while the hunter is walking along the trail. The trail is perpendicular to paths used by the animals, locally denominated carreiro or near to feeding sites. Once the animal's approach is detected, the hunter goes to the location where the animal will most likely be visible and attempts to kill the animal.

Trabuco: A trabuco is a type of trap in which a home shooting device is installed on the ground with a line tied to the trigger of the device. This line is placed across the prey's trail, so when it touches the line, the device is triggered and fired into the animal.

Opportunistic kills: If a hunter is preoccupied with other activities such as fishing or walking and stumbles across an animal he will attempt to kill it, if he is armed.

Firearms (rifles) were the most widely used weapon $(n=372,95 \%$ of hunting events). In nine hunts rifles were used in combination with bow and arrow, in one hunt with a machete, and another with an ax. Remaining kills were done with a club ( $n=7,2 \%$ of hunting events), machete, and bow and arrow (less than $1 \%$ each). Animals $(n=5)$ captured by hand in five hunting events were all Dasypus septemcinctus (long-nosed armadillo), except for one brown brocket deer which was run over by motorcycle.

Of the 451 animals killed, sex was identified in 90\% $(n=406)$ of the individuals, providing a sex ratio for the most commonly killed species (Table 5). The sex ratio was close to 1:1 for most species; however, it was female-biased for the agouti and pampas deer, and male-biased for the white-lipped peccary. 
Table 5. Number of dead individuals by sex and sex ratio of species most killed $(n \geq 15)$ recorded in participatory monitoring of hunting in Xerente indigenous land, March 2014 - February 2015

\begin{tabular}{|c|c|c|c|c|c|}
\hline \multirow[t]{2}{*}{ Species name (popular name) } & \multirow[t]{2}{*}{ Dead $(n)$} & \multirow[t]{2}{*}{$\mathrm{NI}(n)$} & \multicolumn{2}{|c|}{$\begin{array}{l}\text { Sex of killed } \\
\text { animals }(n)\end{array}$} & \multirow[t]{2}{*}{ Sex ratio } \\
\hline & & & Females & Males & \\
\hline Cuniculus paca (paca) & 55 & 2 & 24 & 29 & 121 \\
\hline Dasyprocta sp. (agouti) & 54 & 1 & 34 & 19 & 56 \\
\hline Pecari tajacu (white-collared peccary) & 51 & - & 27 & 24 & 89 \\
\hline $\begin{array}{l}\text { Dasypus novemcinctus (nine-banded } \\
\text { armadillo) }\end{array}$ & 42 & 3 & 17 & 22 & 129 \\
\hline $\begin{array}{l}\text { Mazama gouazoubira (brown brocket } \\
\text { deer) }\end{array}$ & 34 & 1 & 17 & 16 & 94 \\
\hline Ozotoceros bezoarticus (pampas deer) & 29 & - & 21 & 8 & 38 \\
\hline Nasua nasua (coati) & 18 & - & 10 & 8 & 80 \\
\hline Tayassu pecari (white-lipped peccary) & 15 & 1 & 3 & 11 & 367 \\
\hline Total & 298 & 8 & 153 & 137 & - \\
\hline
\end{tabular}

Note. $\mathrm{NI}=$ number of individuals where sex was unidentified; Sex ratio = the number of males for every 100 females.

\section{Discussion}

The predominance of medium and large mammals killed is a common pattern found in both indigenous and non-indigenous groups in the Neotropics (Jerozolimski \& Peres, 2003; Leeuwenberg \& Robinson, 1999; Redford \& Robinson, 1987). In our study, most animals killed were small, such as the paca and agouti (Figure 2, Table 5), indicating that these are the most abundant species in XIL, and may reflect patterns found in the Neotropics, where density is inversely related to body mass (Robinson \& Redford, 1986). However, the Xavante Indians, who have cultural similarities to the Xerente (Maybury-Lewis, 1965) and also inhabit the Cerrado biome, mainly hunt animals of larger body biomass (e.g., tapirs, peccaries, and deer) (Leeuwenberg \& Robinson, 1999).

This difference in prey size of hunted species between indigenous groups may be related to differences in study methods. Data on the Xavante study was collected through hunting recall interviews, and smaller species may have been incompletely remembered and not considered in the results (Leeuwenberg \& Robinson, 1999). Our study, on the other hand, used participatory methods which allowed a more complete record of hunted fauna. This suggests that this alternative may generate more accurate data on the exploitation of natural resources. 
Non-indigenous hunters killed a smaller number of species, which is probably related to the small number of hunting events, as there was no significant difference in hunting techniques and equipment between them and the Xerente (MJP, personal observation). These hunters seem to prefer slightly larger prey. Indigenous and nonindigenous hunters usually differ in game choice (Redford \& Robinson, 1987); however, as the non-indigenous hunters in this study are married to indigenous women and live in Xerente villages, they shared game meat with the families. Therefore differences in game choice are not expected.

Food taboos, despite not being the main focus of this study, show great cultural complexity and are important elements that influence the local management of exploited species (Colding \& Folke, 2001). For example, the tufted capuchin occurs at a relatively high density in XIL, at about 30 individuals per square kilometer (MJP, unpublished data). The low number of this species killed $(n=3)$ is possibly due to primates rarely being consumed among the Xerente for cultural reasons; the tufted capuchin is usually eaten only by elders and children. Similarly, the consumption of primates by the Xavante Indians was not documented by Leeuwenberg \& Robinson (1999) but was observed by Silvius (2004). For the Xerente, this is related to food taboos. Dead animals that were not used as food by hunters for personal reasons were consumed by other Xerente.

The high values in terms of kills and biomass in forested areas reflect the fact that most hunts occurred in this environment (forested areas cover almost twice the area of all the other environments combined). Similar proportions were observed in the number of kills and biomass (Table 3). The Xerente have occupied open areas for hundreds of years and their historical preference was for hunting in open cerrado environments, employing large collective hunts using fire to trap large quantities of prey, as observed among the Xavante (Leeuwenberg \& Robinson, 1999; Welch, 2015). However, the Xerente have virtually abandoned this traditional strategy. According to Xerente hunters, XIL does not have large enough areas and is virtually an isolated fragment in an anthropogenic landscape dominated by farms, which limits the use of fire in hunts. Another factor that may be related to the preference of forest environments for hunting is that animals are more abundant in forest patches than in savanna environments (Read et al., 2010). For example, the paca, a typical forest species (Eisenberg \& Redford, 1999), is currently the preferred species for consumption among Xerente hunters (MJP, personal observation).

The variety of hunting techniques used by the Xerente (Box 1) demonstrates their knowledge and skill, and allows diversification of hunting strategies within a heterogeneous landscape throughout the year. These techniques are also widely used both by indigenous and non-indigenous groups (Alves et al., 2009; Constantino et al., 2008; Pezzuti \& Chaves, 2009; Pezzuti et al., 2004), and may have resulted from long-term contact between the two societies. Despite the relative abandonment of their traditional hunting techniques, the Xerente still hunt using their ecological 
and biological knowledge of the target species to choose which hunting techniques to use and in which environments. Hunting with canoes, for example, is a strategy used to kill species associated with riparian habitats. According to Alves et al. (2009), these abilities and experience are part of a broad depth of knowledge and cultural background that is essential to their survival.

The reduced use of bow and arrow for hunting is also evidence of transformation in traditional hunting systems among the Xerente. Even when used, it was usually combined with rifles, with a single exception. The adoption of shotguns by Xerente hunters follows the same pattern found in Neotropical regions (Jerozolimski \& Peres, 2003) and has been observed among other indigenous groups (Constantino et al., 2008; Prado et al., 2012). Shepard et al. (2012) stated that firearms have become widely available to several indigenous territories in the Amazon, and, despite making hunting more efficient, has changed the relationship between indigenous peoples and wildlife.

The apparent balance in the sex ratio of killed species suggests that Xerente hunters are not selective in this regard. Bias in the sex ratios of agouti and white-lipped peccary may indicate a natural population pattern, as sex identification of this species at time of kill is difficult (Bodmer \& Robinson, 2004). In the case of pampas deer, there is an apparent selectivity for female kills because many hunters avoid killing the males, claiming that the smell of their meat is unpleasant. This apparent female-biased sex ratio can affect the demographic structure of a population by reducing the population's replacement rate (Souza-Mazurek et al., 2000). Since we do not have information on the population parameters of hunted populations in the study area, the possible impacts of selective hunting should be viewed with caution, as this species may have a higher proportion of females (Braga \& Kunyioshi, 2010) to males (Rodrigues, 1996) in the population.

The number of villages and hunters participating in this study represented a good sample of the entire XIL. The proportion of hunters that returned all hunting sheets was satisfactory and enabled reliable estimates of total kills and obtained biomass for participating villages. Hunters were highly interested in collaborating, even with no payment for data collection, which was also the case with the Izoceño Indians in the Bolivian Chaco (Noss et al., 2004). Incomplete data for unsuccessful hunts may have occurred for cultural reasons. Hunters may have been reluctant to admit failure, considering that good hunters tend to be highly respected in Xerente society (MJP, personal observation). This demonstrates that cultural aspects should be carefully addressed in community-based research and management-related activities (Luzar et al., 2011). 


\section{Implications for conservation}

Participatory monitoring of hunting provided an important data set on hunting activities and wildlife use that will help outline future conservation and management plans in XIL. Our findings highlight species that deserve special attention in these future strategies, such as the more intensely harvested, and the most vulnerable and threatened species. Changes in traditional hunting activities should also be considered, as firearms have a higher impact on wildlife than traditional weapons (Shepard et al., 2012).

It should be pointed out that XIL is often subject to illegal hunting. This activity is almost impossible to monitor and, consequently, the overall impact of hunting activity within XIL is not known. An additional threat comes from agriculturebased development around XIL. These projects are fostered by the federal and state governments and the private sector. They advocate for the construction of state highways crossing XIL to facilitate marketing of products. This will increase access to the territory by illegal hunters, placing local wildlife under greater pressure. The management and conservation of wildlife within XIL must be supported by enforcement agencies and the implementation of measures to prevent increasing impacts of human activities in general, and particularly in the context of the new road construction.

\section{Considerations}

Participating hunters were reasonably literate (either in Portuguese or their native language), facilitating an understanding of the study's purposes and all training activities. Noncompliance with data recording for unsuccessful hunts is an issue that must be addressed in future research. This may be achieved through a complementary method for measuring the proportion of unsuccessful hunting. Xerente hunters have access to technologies such as smartphones and their use in future natural resource monitoring programs should be explored due to the valuable contribution these devices can make to a monitoring system (Liebenberg et al., 2017).

This study was the first to use participatory monitoring methods to address hunting activities in the Cerrado biome of Brazil. Considering the Xerente people as an example of a traditional society that exploits the Cerrado, findings and data presented here could help in the development of other monitoring programs that would contribute to a better understanding of the patterns of wildlife use. 


\section{Conclusions}

Medium- and large-sized mammals were the most hunted species, and sex ratio for most species was balanced. Hunting activities were predominant in forest environments and different hunting techniques were employed. Firearms were the main weapon used. The traditional collective hunting strategy of using fire to trap large quantities of prey is no longer carried out, and traditional weapons such as the bow and arrow are seldom used. However, knowledge about habitat use and trophic relations, especially the dietary habits of most game species, are crucial for the success of Xerente hunting activities. The involvement of hunters as monitors resulted in a solid data set about hunting activity in the monitoring period, demonstrating that participatory monitoring of hunting has great potential for continuous assessment of wildlife use in XIL. The large voluntary participation of most hunters demonstrates their interest in monitoring game use and reflects true concern about wildlife stocks. This reaffirms the potential of community involvement in research on the use of wildlife.

\section{Acknowledgments}

We are sincerely grateful to all the Xerente hunters/monitors and other aids who participated in this study. We are thankful to the Akwẽ Indígenous Association and Indigenous Organization of Aldeia Ktẽpo Xerente. We thank Dr. Glenn H. Shepard Jr. for his help in conducting this study, Leila de Souza for her support together with the National Indian Foundation, Elildo Carvalho Jr. for help with the text, and two anonymous reviewers for helpful comments on this manuscript. This study was funded by the Rufford Small Grants Foundation.

\section{References}

Alves, R. R. N., Mendonça, L. E. T., Confessor, M. V. A., Vieira, W. L. S., \& Lopez, L. C. S. (2009). Hunting strategies used in the semi-arid region of northeastern Brazil. Journal of Ethnobiology and Ethnomedicine, 5(12), 1-16.

Berkes, F. (2004). Rethinking community-based conservation. Conservation Biology, 18(3), 621-630.

Bodmer, R. E., \& Puertas, P. E. (1999). Community-based comanagement of wildlife in the Peruvian Amazon. In J. G. Robinson \& E. L. Bennett (Eds.), Hunting for sustainability in tropical forests (pp. 395-409). New York, NY: Columbia University Press. 
Bodmer, R. E., \& Robinson, J. G. (2004). Evaluating the sustainability of hunting in the Neotropics. In K. M. Silvius, R. E. Bodmer, \& J. M. V. Fragoso (Eds.), People in nature: Wildlife conservation in South and Central America (pp. 299-323). New York: Columbia University Press. doi.org/10.7312/silv12782-019

Braga, F. G., \& Kunyioshi, Y. S. (2010). Estimativas de parâmetros populacionais e demográficos de Ozotoceros bezoarticus (Artiodactyla, Cervidae) em Piraí do Sul, Paraná, sul do Brasil. Iheringia Zoologia, 100(2), 105-110. doi.org/10.1590/ S0073-47212010000200003

Brown, K. (2003). Three challenges for a real people-centred conservation. Global Ecology and Biogeography, 12(2), 89-92. doi.org/10.1046/j.1466-822X. 2003.00327.x

Colding, J., \& Folke, C. (2001). Social taboos: "Invisible” systems of local resource management and biological conservation. Ecological Applications, 11(2), 584-600.

Constantino, P., Carlos, H. S. A., Ramalho, E. E., Rostant, L., Marinelli, C. E., Teles, D., ... Valsecchi, J. (2012). Empowering local people through community-based resource monitoring: A comparison of Brazil and Namibia. Ecology and Society, 17(4), 22. doi.org/10.5751/ES-05164-170422

Constantino, P., Fortini, L., Kaxinawa, F., Kaxinawa, A., Kaxinawa, E., Kaxinawa, L., \& Kaxinawa, J. (2008). Indigenous collaborative research for wildlife management in Amazonia: The case of the Kaxinawá, Acre, Brazil. Biological Conservation, 141(11), 2718-2729. doi.org/10.1016/j.biocon.2008.08.008

Danielsen, F., Burgess, N. D., \& Balmford, A. (2005). Monitoring matters: Examining the potential of locally-based approaches. Biodiversity and Conservation, 14(11), 2507-2542. doi.org/10.1007/s10531-005-8375-0

Eisenberg, J. F., \& Redford, K. H. (1999). Mammals of the Neotropics (Vol. 3). Chicago and London: The University of Chicago Press.

Emmons, L. H., \& Feer, F. (1990). Neotropical rainforest mammals (2nd ed.). Chicago and London: The University of Chicago Press.

Farias, A. (1994). Notícia histórica sobre os Akwen-Xerente. Boletim do Museu Paraense Emílio Goeldi: Antropologia, 10(1), 21-41.

Ferraz, G., Marinelli, C., \& Lovejoy, T. (2008). Biological monitoring in the Amazon: Recent progress and future needs. Biotropica, 40(1), 7-10.

Giraldin, O., \& Silva, C. (2002). Ligando mundos: Relação entre Xerente ea sociedade circundante no século XIX. Boletim do Museu Paraense Emílio Goeldi: Antropologia, 18(2), 1-16. 
Hill, K., Padwe, J., Bejyvagi, C., Bepurangi, A., Jakugi, F., Tykuarangi, R., \& Tykuarangi, T. (1997). Impact of hunting on large vertebrates in the Mbaracayu Reserve, Paraguay. Conservation Biology, 11(6), 1339-1353. doi.org/ 10.1046/j.1523-1739.1997.96048.x

IBGE (Instituto Brasileiro de Geografia Estatística). (2010). Censo 2010. Retrieved from www.censo2010.ibge.gov.br/terrasindigenas/

IUCN (International Union for Conservation of Nature). (2014). The IUCN red list of threatened species. Version 2014.3. Retrieved from www.iucnredlist.org/

Iwamura, T., Lambin, E. F., Silvius, K. M., Luzar, J. B., \& Fragoso, J. M. (2014). Agent-based modeling of hunting and subsistence agriculture on indigenous lands: Understanding interactions between social and ecological systems. Environmental Modelling \& Software, 58, 109-127. doi.org/10.1016/j. envsoft.2014.03.008

Jerozolimski, A., \& Peres, C. A. (2003). Bringing home the biggest bacon: A cross-site analysis of the structure of hunter-kill profiles in Neotropical forests. Biological Conservation, 111, 415-425. doi.org/10.1016/S0006-3207(02)00310-5

Klink, C. A., \& Machado, R. B. (2005). A conservação do Cerrado brasileiro. Megadiversidade, 1(1), 147-155.

Krieger, W., \& Krieger, G. (1994). Dicionário escolar Xerente-Português, PortuguêsXerente. Rio de Janeiro: Junta das Missóes Nacionais da Convenção Batista Brasileira.

Leeuwenberg, F. J., \& Robinson, J. G. (1999). Traditional management of hunting by a Xavante community in central Brazil: The search for sustainability. In J. G. Robinson \& E. L. Bennett (Eds.), Hunting for sustainability in tropical forests (pp. 375-393). New York, NY: Columbia University Press.

Liebenberg, L., Steventon, J., Brahman, !N., Benadie, K., Minye, J., Langwane, H., \& Xhukwe, Q. (2017). Smartphone icon user interface design for nonliterate trackers and its implications for an inclusive citizen science. Biological Conservation, 208, 155-162. doi.org/10.1016/j.biocon.2016.04.033

Lopes, G. P., Valsecchi, J., Vieira, T. M., Amaral, P. V., \& Costa, E. W. M. (2012). Hunting and hunters in lowland communities in the region of the middle Solimóes, Amazonas, Brazil. Uakari, 8, 7-18.

Luzar, J. B., Silvius, K. M., Overman, H., Giery, S. T., Read, J. M., \& Fragoso, J. M. V. (2011). Large-scale environmental monitoring by indigenous peoples. BioScience, 61(10), 771-781. doi.org/10.1525/bio.2011.61.10.7 
Marinho-Filho, J., Rodrigues, F. H. G., \& Juarez, K. M. (2002). The Cerrado mammals: Diversity, ecology, and natural history. In P. S. Oliveira \& R. J. Marquis (Eds.), The Cerrados of Brazil: Ecology and natural history of a Neotropical savanna (pp. 266-284). New York, NY: Columbia University Press.

Maybury-Lewis, D. (1965). Some crucial distinctions in central Brazilian ethnology. Anthropos, 60, 340-358.

MMA (Ministério do Meio Ambiente). (2014). Espécies Ameaçadas_Lista 2014. Retrieved from www.icmbio.gov.br/portal/biodiversidade/fauna-brasileira/listade-especies.html?start $=50$

Moller, H., Berkes, F., O’Brian Lyver, P., \& Kislalioglu, M. (2004). Combining science and traditional ecological knowledge: Monitoring populations for co-management. Ecology and Society, 9(3). doi.org/10.5751/ES-00675-090302

Myers, N., Mittermeier, R. A., Mittermeier, C. G., da Fonseca, G. A. B., \& Kent, J. (2000). Biodiversity hotspots for conservation priorities. Nature, 403(6772), 853-858. doi.org/10.1038/35002501

Noss, A. J., Cuéllar, E., \& Cuéllar, R. L. (2004). An evaluation of hunter selfmonitoring in the Bolivian Chaco. Human Ecology, 32(6), 685-702. doi.org/ $10.1007 /$ s10745-004-6832-0

Noss, A. J., Oetting, I., \& Cuéllar, R. L. (2005). Hunter self-monitoring by the Isoseño-Guaraní in the Bolivian Chaco. Biodiversity and Conservation, 14(11), 2679-2693. doi.org/10.1007/s10531-005-8401-2

Nowak, R. M. (1999). Walker's mammals of the world (6th ed., Vol. 1). Baltimore, MD: Johns Hopkins University Press.

Ohl-Schacherer, J., Shepard, G. H., Jr., Kaplan, H., Peres, C. A., Levi, T., \& Yu, D. W. (2007). The sustainability of subsistence hunting by Matsigenka native communities in Manu National Park, Peru. Conservation Biology, 21(5), 1174-1185. doi.org/10.1111/j.1523-1739.2007.00759.x

Peres, C. A., \& Palacios, E. (2007). Basin-wide effects of game harvest on vertebrate population densities in Amazonian forests: Implications for animalmediated seed dispersal. Biotropica, 39(3), 304-315. doi.org/10.1111/j.17447429.2007.00272.x

Pezzuti, J. C. B., \& Chaves, R. P. (2009). Etnografia e manejo de recursos naturais pelos índios Deni, Amazonas, Brasil. Acta Amazonica, 39(1), 121-138. doi.org/ 10.1590/S0044-59672009000100013 
Pezzuti, J. C. B., Rebêlo, G. H., Félix-Silva, D., Pantoja-Lima, J., \& Ribeiro, M. C. (2004). A caça e a pesca no Parque Nacional do Jaú. In S. H. Borgres, S. Iwanaga, C. C. Durigan, \& M. R. Pinheiro (Eds.), Janelas para a biodiversidade no Parque Nacional do Jaú: Uma estratégia para o estudo da biodiversidade na Amazônia (pp. 214-226). Manaus: Fundação Vitória Amazônica.

Prado, H. M., Forline, L. C., \& Kipnis, R. (2012). Hunting practices among the Awá-Guajá: Towards a long-term analysis of sustainability in an Amazonian indigenous community. Boletim do Museu Paraense Emílio Goeldi: Ciências Humanas, 7(2), 479-491. doi.org/10.1590/S1981-81222012000200010

Read, J. M., Silvius, K. M., Luzar, J., Overman, H., Cummings, A., \& Giery, S. T. (2010). Space, place, and hunting patterns among indigenous peoples of the Guyanese Rupununi region. Journal of Latin American Geography, 9(3), 213-243. doi.org/10.1353/lag.2010.0030

Redford, K. H., \& Robinson, J. G. (1987). The game of choice: Patterns of Indian and colonist hunting in the Neotropics. American Anthropologist, 89(3), 650-667. doi.org/10.1525/aa.1987.89.3.02a00070

Ribeiro, J. F., \& Walter, B. M. (2008). As principais fitofisionomias do bioma Cerrado. In S. M. Sano, S. P. Almeida, \& J. F. Ribeiro (Eds.), Cerrado: Ecologia e flora (pp. 19-45). Brasília: EMBRAPA.

Robinson, J. G., \& Redford, K. H. (1986). Body size, diet, and population density of Neotropical forest mammals. American Naturalist, 128(5), 665-680. doi.org/ $10.1086 / 284596$

Robinson, J. G., \& Redford, K. H. (1991). Sustainable harvest of Neotropical forest mammals. In J. G. Robinson \& K. H. Redford (Eds.), Neotropical wildlife use and conservation (pp. 415-429). Chicago: University of Chicago Press.

Rodrigues, F. H. G. (1996). História natural e biologia comportamental do veado campeiro (Ozotoceros bezoarticus) em Cerrado do Brasil Central (Master's thesis). Universidade Estadual de Campinas, Brazil.

Shepard, G. H., Jr. (2014). Hunting in Amazonia. In H. Seline (Ed.), Encyclopaedia of the history of science, technology, and medicine in non-Western cultures (7th ed., pp. 1-7). Dordrecht: Springer. doi.org/10.1007/978-94-007-3934-5_9909-1

Shepard, G. H., Jr., Levi, T., Neves, E. G., Peres, C. A., \& Yu, D. W. (2012). Hunting in ancient and modern Amazonia: Rethinking sustainability. American Anthropologist, 114(4), 652-667. doi.org/10.1111/j.1548-1433.2012.01514.x

Sick, H. (1986). Ornitologia brasileira. Brasília: Editora Universidade de Brasilia. 
da Silva, J. M. C., \& Bates, J. M. (2002). Biogeographic patterns and conservation in the South American Cerrado: A tropical savanna hotspot. BioScience, 52(3), $225-233$.

Silvius, K. M. (2004). Bridging the gap between western scientific and traditional indigenous wildlife management. In K. M. Silvius, R. E. Bodmer, \& J. M. V. Fragoso (Eds.), People in nature: Wildlife conservation in South and Central America (pp. 37-49). New York, NY: Columbia University Press. doi.org/10.7312/ silv12782-003

Souza-Mazurek, R. R., Pedrinho, T., Feliciano, X., Hilário, W., Gerôncio, S., \& Marcelo, E. (2000). Subsistence hunting among the Waimiri Atroari Indians in central Amazonia, Brazil. Biodiversity and Conservation, 9, 579-596. doi.org/ 10.1023/A:1008999201747

Trolle, M., Bissaro, M. C., \& Prado, H. M. (2006). Mammal survey at a ranch of the Brazilian Cerrado. Biodiversity and Conservation, 16(4), 1205-1211. doi.org/10.1007/s10531-006-9106-x

Vieira, M. A. R. M., Muhlen, E. M., \& Shepard, G. H. (2015). Participatory monitoring and management of subsistence hunting in the Piagaçu-Purus Reserve, Brazil. Conservation and Society, 13(3), 254-264. doi.org/10.4103/09724923.170399

Welch, J. R. (2015). Learning to hunt by tending the fire: Xavante youth, ethnoecology, and ceremony in central Brazil. Journal of Ethnobiology, 35(1), 183-208. doi.org/10.2993/0278-0771-35.1.183 
This text is taken from Human Ecology Review, Volume 23, Number 1, 2017, published 2017 by ANU Press, The Australian National University, Canberra, Australia.

dx.doi.org/10.22459/HER.23.01.2017.02 